texture, colour, flavour and artistry in cooking are as important as calories, vitamins and mineral salts in the ultimate value of food consumed. We maintain that with the present small allowance of fat the standard of much of our cooking is deteriorating, and a generation is growing up which has little idea of the art of good cooking. We would put in a plea for at least $\mathrm{I}-\mathrm{r} \frac{1}{2} \mathrm{lb}$. of fat for each person weekly for cooking and table use.

\title{
REFERENCES
}

Hutchison, R. \& Mottram, V. H. (1936). Food and the Principles of Dietetics, 8th ed., p. 44. London: Edward Arnold and Co.

Macdonald, G. (1938). Food Facts and Diet Planning, rst ed., p. 76. London: Macmillan. Plimmer, V. (194I). Food Values in War Time, p. 69. London: Longmans, Green and Co.

\section{The Nutritive Value of Fats, with Special Reference to Butter and Margarine}

\section{By J. A. B. SмIтн, Hannah Dairy Research Institute, Kirkhill, Ayr}

It is well known that fats can readily be fortified with the chief fat-soluble vitamins and that the margarine available in this country throughout the year is now usually as rich in these vitamins as summer butter, and much richer than winter butter. In the present paper, therefore, there is no need to deal with the fat-soluble vitamins. The term 'fat' will be used in its true chemical sense, to denote triglycerides of fatty acids. It will be assumed that in all the feeding experiments referred to the vitamin, mineral and protein contents of the experimental diets were adequate, so that it is the nutritive value of the triglycerides themselves which is under review.

For our purpose to-day the fatty acids present as glycerides in edible fats may be regarded as falling into three main groups. First, there are the three fatty acids, palmitic, stearic and oleic. They can well be put in one class because they appear to occur in all edible fats, whether animal or vegetable, and are not likely to be the cause of any differences in nutritive value which may exist. Secondly, there are the more unsaturated acids, linoleic, linolenic and arachidonic, which are rich in double bonds, and tend therefore to be readily oxidized. This class includes the so-called essential fatty acids (Burr \& Burr, 1929, 1930). There is no need, however, to deal with these here. If they are essential for man, they are certainly required in very small amounts, and since they are widely distributed in nature they are not likely to be deficient, except perhaps in diets of a very unusual type. Thirdly, there are the volatile fatty acids, butyric, hexanoic and octanoic, which occur as glycerides in butter and which might conceivably give butter some special nutritive properties. In addition to the acids in these three main groups, one other fatty acid has been much discussed in recent years. It is the solid unsaturated acid first isolated from butter by Bertram (r928) and named by him vaccenic acid. It is isomeric with oleic acid, but its one double bond is in the II : I2 position instead of in the $9:$ Io position.

The nutritive value of a fat may be affected by its absorbability, and possibly also by its animal or vegetable origin. The main part of the subject will therefore be dealt with under these two main headings. 


\section{Absorbability}

About 25 years ago Langworthy (1923) summarized the results of a long series of experiments which had been made by Deuel, Holmes, Langworthy and others on the absorbability of different fats. Some twenty-three animal fats, thirty-four vegetable fats and six hydrogenated oils were studied. It was found that most of them were absorbed by man to the extent of $95 \%$ or more, the few exceptions being fats with melting-points well above body temperature. Partially hydrogenated vegetable fats and mixtures of completely hydrogenated fats blended with unsaturated fats were all found by Deuel \& Holmes (1921, 1922) to be almost completely absorbed, provided the melting-point of the mixture was below $46^{\circ}$. With blends of ground-nut oil, for example, the absorbability was $98.1 \%$ when the oil melted at $37^{\circ}$, and was still $96.5 \%$ when the melting-point was raised to $43^{\circ}$. At melting-points of 50 and $53^{\circ}$, however, the absorbability was reduced to 92 and $79 \%$. Holmes (r925; quoted by Deuel, 1946) found that three types of margarine made from animal fat were almost completely absorbed even when they contained a proportion of 'oleostearin', a fat which when given alone was absorbed to the extent of only $80 \%$.

The actual rate of absorption was studied by Steenbock, Irwin \& Weber (1936) by giving rats, which had previously fasted for $48 \mathrm{hr}$., $1.5 \mathrm{ml}$. of melted fat by stomach tube, and finding how much of the fat was absorbed after intervals up to $12 \mathrm{hr}$. Butterfat was absorbed slightly more quickly than the others during the first $2 \mathrm{hr}$., but in longer periods the amounts of butterfat, maize oil and partially hydrogenated vegetable oils absorbed were all much the same. In somewhat similar experiments Deuel \& Hallman (1940) and Deuel, Hallman \& Leonard (1940) found that butterfat, hydrogenated cotton-seed oil and coconut oil were all absorbed with equal efficiency, the rate of absorption depending not on the nature of the fat, but on the surface area of the portion of alimentary tract concerned.

More recently, Deuel (1946) investigated the absorbability of a modern brand of margarine known to be made from vegetable oils and having a melting-point below body temperature. Over a 3 day period five men and five women were given a basal diet low in fat to which butter or margarine was added. With the seven people who received the margarine diet, the average amount of fat eaten daily was $260 \mathrm{~g}$., and the percentage absorption, corrected for metabolic faecal fat, was $98,94,96,96,97,99$ and 97, with an average of 97. For the three who received the butter diet, the average amount of fat eaten daily was only $146 \mathrm{~g}$., and the percentage absorption was 100,99 , 92, with an average of 97 . The margarine fat was therefore absorbed just as well as the butterfat, although much more of it was eaten. Another important point was that the other constituents of the diet were digested and absorbed as efficiently with margarine as with butter. In recent experiments with rats Abrams, Ashton, Ritson \& Wilkinson (1947) have studied the absorbability of fats used at present in Britain for manufacturing margarine and cooking fats. So far only a very brief account of the work is available, but it appears to confirm the earlier results.

The importance of the effects of the melting-point of the fat and of the protein content of the diet on fat absorption has been studied by Barnes, Primrose $\&$ Burr 
(1944). From the results which they obtained, and from the others which have been quoted, it is clear that absorption of fat, whether animal or vegetable, is almost complete, provided its melting-point does not exceed body temperature by more than a few degrees and provided the composition of the diet as a whole is within what may reasonably be regarded as normal limits. The fact that butter is not more efficiently absorbed than other fats suggests that fat absorption is not measurably increased by the presence of the lower fatty acids in butter.

\section{Animal and vegetable fat}

The present state of knowledge of the relative values of animal and vegetable fat will be grasped most readily by considering the different views held by three separate groups of research workers. One group, working in Holland, believes that summer butter has nutritional qualities superior to those of other fats. A second group, working at Wisconsin, claims that butterfat is superior to other fats but only under very limited circumstances. The third group, which includes many workers in several different countries, has been unable to find any significant difference whatever between the nutritive value of butter and that of several other fats.

\section{The work of the Dutch group}

The more recent experiments of the Dutch workers were made by Boer, Jansen \& Kentie (1947) and have been discussed by Jansen (1948) and Kentie (1947). The nutritive value of summer butterfat was compared with that of ground-nut, olive and rape-seed oils when given to rats in diets containing $10 \%$ of fat. The growth with summer butterfat was slightly but significantly greater than with the other fats. After Io weeks on butterfat, for example, the rats had an average weight of $190 \mathrm{~g}$. as compared with $173 \mathrm{~g}$. on ground-nut oil. By fractionating the fatty acids of the butter, the substance responsible for the superior growth was traced to the fraction containing $\mathrm{C}_{18}$ acids, and on hydrogenating this fraction the activity of the substance was destroyed. It therefore appeared to be a $\mathrm{C}_{18}$ unsaturated fatty acid, and the most likely substance satisfying these requirements was vaccenic acid, which had been found to exist in small amounts in butter but not in vegetable fats.

Boer and his colleagues isolated vaccenic acid from butter in crude form (m.p. $36^{\circ}$, i.v. $8 \mathrm{r} \cdot 4$ ), added it to rape-seed oil and found the mixture to give greater growth than rape-seed oil alone. They then prepared vaccenic acid from an entirely different source, namely, from China-wood oil by partial hydrogenation. In their earlier experiments with this particular sample of vaccenic acid they observed a significant difference in growth-promoting properties between rape-seed oil alone and rape-seed oil containing the vaccenic acid preparation (Boer, Jansen, Kentie \& Knol, 1947). It is important to note, however, that in his latest published report Jansen (1948) stated that, when the vaccenic acid was purified further, consistent results were not obtained. It may be, therefore, that very small traces of some impurity constituted the actual growthpromoting factor; certainly the work which is discussed in the next two sections makes it difficult to believe that vaccenic acid has the growth-promoting properties which the 
Dutch workers at first ascribed to it. For the present it should be noted that the difference observed by the Dutch workers between growth on summer butter and on vegetable fat was usually small and became apparent only after the feeding experiments had gone on for 4 or 5 weeks.

\section{The work of the Wisconsin group}

Ten years ago Schantz, Elvehjem \& Hart (1937-8) found that lactose was completely utilized by rats only when the diet was not abnormally low in fat, and in the course of their work they noticed that rats appeared to grow better on some fats than on others. They therefore made a series of experiments to determine the relative value of a number of different fats for growth (Schantz, Elvehjem \& Hart, 1940; Schantz, Boutwell, Elvehjem \& Hart, 1940a, b; Boutwell, Geyer, Elvehjem \& Hart, 1941, I $943 a, b$ ). The fats were incorporated at a $4 \%$ level in skim milk and the milk was given ad lib. to weanling rats. Some of the main results are summarized in Tables $\mathrm{r}$, 2 and 3 , the more important conclusions being as follows. (I) When lactose was the main carbohydrate in the diet, maize oil and most of the other fats tested, particularly those of vegetable origin, gave poorer growth than butter. (2) The factor responsible for the superiority of butter was contained in the saturated acid fraction of the fat (Table 1). It was not present in the unsaponifiable fraction or in the unsaturated acid fraction, but it could be formed by hydrogenating the unsaturated fraction. The addition of lecithin, sphingomyelin, ethanolamine or choline to the maize-oil diet did not increase its value. (3) The difference between butter and other fats diminished as the rats grew older, and did not exist even with very young rats when the lactose of the diet was replaced by other carbohydrates (Table 3).

It will be observed that the findings of the Wisconsin workers differ markedly from those of the Dutch workers. At Wisconsin butter was found to be superior to other fats only when the experimental animals were very young and when the carbohydrate of their diet consisted almost entirely of lactose. Moreover, the active principle was believed by the Wisconsin group to be in the saturated acid fraction of the butter acids. They found that it was produced when the unsaturated fraction was hydrogenated, and so could not be vaccenic acid.

\section{Experiments at other research stations}

At Los Angeles, Deuel, Movitt, Hallman \& Mattson (1944) made a series of tests on 250 male and 309 female weanling rats which were given diets composed mainly of dried skim-milk solids $(70.6 \%)$ and fat $(29.4 \%)$, with the necessary vitamins and minerals. The sole source of carbohydrate, therefore, was lactose, and yet at no time during a 12 week period could any difference be detected between the results for butter and those for margarine and the oils of maize, cotton-seed, ground-nut and soya bean. There was no difference in the weights of the various groups of rats, in the efficiency with which the different diets were utilized, or in tibia lengths as determined by X-ray examination.

Since it appeared from the results obtained at Wisconsin that the superiority of 
Table 1. Average gains in weight of rats given rations containing butterfat, maize oil, and maize oil to which different fractions of butterfat had been added*

Average gain in weight during first 3 weeks

at or oil tested

(g.)

\section{Butter}

Maize oil

Maize oil + glycerides of volatile acid fraction of butterfat $\dagger$

Maize oil + glycerides of unsaturated acid fraction of butterfat $\$$

Maize oil + glycerides of saturated fraction of butterfat $\ddagger$

$\begin{array}{cc}\text { Males } & \text { Females } \\ 70 & 66 \\ 63 & 47 \\ 48 & 51 \\ 63 & 55 \\ 82 & 73\end{array}$

- Taken from the work of Schantz et al. (1940b).

+ Separated by steam distillation.

I Separated by crystallization of the lead soaps of the saturated acids.

Table 2. Average gains in weight of rats given different fats incorporated in rations containing lactose as the sole carbohydrate and also in rations containing a mixture of carbohydrates*

Gain in weight after 5 weeks (B.)†

\begin{tabular}{|c|c|c|c|c|c|c|c|c|c|}
\hline $\begin{array}{l}\text { Type of } \\
\text { carbohydrate } \\
\text { in ration }\end{array}$ & $\begin{array}{l}\text { Butter- } \\
\text { fat }\end{array}$ & $\begin{array}{c}\text { Maize } \\
\text { oil }\end{array}$ & $\begin{array}{c}\text { Coco- } \\
\text { nut } \\
\text { oil }\end{array}$ & $\begin{array}{c}\text { Cotton- } \\
\text { seed } \\
\text { oil }\end{array}$ & $\begin{array}{c}\text { Soya- } \\
\text { bean } \\
\text { oil }\end{array}$ & $\begin{array}{c}\text { Olive } \\
\text { oil }\end{array}$ & $\begin{array}{l}\text { Ground- } \\
\text { nut } \\
\text { oil }\end{array}$ & 'Crisco't & Lard \\
\hline $\begin{array}{l}\text { ctose } \\
\text { xed }\end{array}$ & $\begin{array}{l}169 \\
199\end{array}$ & $\begin{array}{l}136 \\
193\end{array}$ & $\begin{array}{l}154 \\
219\end{array}$ & $\begin{array}{l}155 \\
200\end{array}$ & $\begin{array}{l}138 \\
204\end{array}$ & $\begin{array}{l}r 39 \\
184\end{array}$ & $\begin{array}{l}\times 38 \\
199\end{array}$ & $\begin{array}{l}156 \\
200\end{array}$ & $\begin{array}{l}163 \\
202\end{array}$ \\
\hline
\end{tabular}

carbohydrate

- Taken from the resuits of Boutwell et al. (1943b).

$\dagger$ Six rats in each group.

$\ddagger$ 'Crisco' is hydrogenated cotton-seed oil.

Table 3. Average gains in weight of rats given different fats and margarines in the presence of lactose and of mixed carbohydrates, and efficiency with which the various diets were utilized*

Fat or oil tested

Butterfat

Maize oil

Margarine from animal fat:

Type I

Type 2

Type 3

Margarine from vegetable fat:

Type I

Type 2

Type 3

Type 4

\begin{tabular}{|c|c|c|c|}
\hline \multicolumn{2}{|c|}{$\begin{array}{l}\text { Gain in weight } \\
\text { after } 6 \text { weeks (g.) }\end{array}$} & \multicolumn{2}{|c|}{$\begin{array}{l}\text { Efficiency of } \\
\text { utilization }(\%)\end{array}$} \\
\hline Lactose & $\begin{array}{c}\text { Mixed } \\
\text { carbohydrate }\end{array}$ & Lactose & $\begin{array}{c}\text { Mixed } \\
\text { carbohydrate }\end{array}$ \\
\hline 219 & 241 & 39 & $4 I$ \\
\hline 177 & 224 & 36 & $4 I$ \\
\hline 212 & 252 & 41 & 42 \\
\hline 214 & 240 & 34 & 40 \\
\hline 206 & 224 & 37 & 39 \\
\hline 212 & 242 & 37 & 40 \\
\hline 202 & 224 & 35 & 39 \\
\hline 193 & 246 & 32 & 42 \\
\hline 194 & 250 & 34 & 41 \\
\hline
\end{tabular}

- From the results of Boutwell et al. (1943b).

+ Efficiency $=\frac{\text { Gain in weight (g.) }}{\text { Food eaten (g.) }} \times 100$. 
butterfat might not be detectable unless the rats were given the experimental diets at a very early age, Deuel \& Movitt (1945) made another series of tests with over 200 rats. The mothers of the rats received the experimental diets when their young were 7 days old, and the young rats when they were 14 days old. Again, butter was not found to be superior to margarine or to the oils of maize, cotton-seed, ground-nut or soya bean. In other experiments with very young rats, Zialcita \& Mitchell (1944) at Illinois gave the

Table 4. Growth of rats on rations containing butterfat and maize oil*

\begin{tabular}{|c|c|c|c|c|}
\hline \multirow[b]{3}{*}{ Variable measured } & \multicolumn{4}{|c|}{ Controlled feeding } \\
\hline & \multicolumn{2}{|c|}{ Weaned at I week $\nmid$} & \multicolumn{2}{|c|}{ Weaned at 2 weeks $\downarrow$} \\
\hline & Butterfat & Maize oil & Butterfat & Maize oil \\
\hline \multirow[t]{4}{*}{$\begin{array}{l}\text { Gain in weight at } 9 \text { weeks (g.) } \\
\text { Body length at } 9 \text { weeks (mm.) }\end{array}$} & $\begin{array}{l}133.7 \\
187.2\end{array}$ & $\begin{array}{l}137.5 \\
188.9\end{array}$ & $\begin{array}{l}132 \cdot 8 \\
190 \cdot 1\end{array}$ & $\begin{array}{l}136.8 \\
187.9\end{array}$ \\
\hline & \multicolumn{4}{|c|}{ Feeding $a d$ lib. } \\
\hline & \multicolumn{2}{|c|}{ Exp. $I \S$} & \multicolumn{2}{|c|}{ Exp. 2\| } \\
\hline & Butterfat & Maize oil & Butterfat & Maize oil \\
\hline $\begin{array}{l}\text { Gain in weight (g.) } \\
\text { Body length (mm.) } \\
\text { Food consumed (g.) }\end{array}$ & $\begin{array}{l}.143 \cdot 4 \\
204 \cdot 4 \\
361 \cdot 4\end{array}$ & $\begin{array}{l}169 \cdot 8 \\
215.2 \\
397 \cdot 4\end{array}$ & $\begin{array}{r}97 \cdot 8 \\
189 \cdot 0 \\
198 \cdot 0\end{array}$ & $\begin{array}{r}91 \cdot 0 \\
182 \cdot 7 \\
183 \cdot 3\end{array}$ \\
\hline \multicolumn{5}{|c|}{$\begin{array}{l}\text { From the results of Zialcita \& Mitchell (1944). } \\
\text { t Eight pairs of rats, three male, five female. } \\
\text { I Eight pairs of rats, four male, four female. } \\
\$ \text { Six males in each group, fed for } 6 \text { weeks. } \\
\text { II Five males in each group, fed for } 3 \text { weeks. Exp. } 2 \text { was the same as Exp. I except tinat } 6 \% \text { of liv } \\
\text { stract was added to the diet. }\end{array}$} \\
\hline
\end{tabular}

animals, from 7 days old, and some from 14 days old, milks made to resemble rat's milk but containing $15 \%$ of butterfat or maize oil. The rats were paired according to litter, sex and weight, and were given the milks by a syringe until normal weaning age. They were then given rations containing butterfat or maize oil 27 , ether-extracted skim milk powder 60 , casein 7 and salt mixture $6 \%$ with the necessary vitamins and minerals. The results are summarized briefly in Table 4. Again there was no evidence to suggest that butterfat was superior to maize oil in promoting growth.

Further work from Los Angeles by Deuel, Movitt \& Hallman (1944) showed that, when rats were given a number of different fats in rations which were otherwise adequate, the fertility of male and female rats and the milk yields of the females as measured by the weights of the young at 14 or 21 days old were not affected by the type of fat. Even when butter and a vegetable margarine were compared over a period of $4 \frac{1}{2}$ years, and reproduction and growth rate were studied over ten generations in which the lineage was through the first litters, and over eight generations in which the lineage was through the second litters, it was found that margarine could adequately replace butter (Deuel, Hallman \& Movitt, I945). When a growth hormone preparation was injected so that rats grew more rapidly than normal, diets containing margarine or vegetable fats supported this rapid growth just as efficiently as similar diets containing butterfat (Deuel, Hendrick \& Crockett, 1946). 
The Wisconsin workers had suggested that butter was no better than the other fats in the experiments of Deuel and his colleagues because they did not use fat-extracted skim milk powder. For this reason Deuel, Hendrick, Movitt, Crockett, Smyth \& Winzler (1946) repeated some of the essential parts of their work with fat-extracted milk powder, but again no difference could be found between the various fats tested.

Not only has growth been used as an indication of the equality of fats, but the carcasses of the rats fed on the different diets have been analysed by several workers; no difference in favour of the butter rations was detected (Boutwell et al. 1943 $b$; Deuel, Hallman, Movitt, Mattson \& Wu, 1944; Zialcita \& Mitchell, 1944). In fact, in the analyses published by Boutwell et al. (1943 $b$ ) for rats which had appeared to grow better on butterfat in the presence of lactose than on maize oil, the average protein content of the dried carcasses was as much as $55.0 \%$ for the rats given maize oil as compared with $53.5 \%$ for those given butterfat. Slightly more fat $(34.8 \%$ of the dry weight of the carcasses as compared with $32.8 \%$ ) was stored by the rats fed on the butter diets, but greater storage of fat is not necessarily an indication of better nutrition.

Evidence that butter is no better than many other fats has been published not only from the laboratories of Deuel at Los Angeles and Mitchell at Illinois but also from other parts of the United States (Harris \& Mosher, 1940; Parrish, Shimer \& Hughes, 1946), from Britain (Henry, Kon, Hilditch \& Meara, 1945) and from Sweden (Euler, Euler \& Säberg, 1942, 1943; Euler, Euler \& Rönnestam-Säberg, 1947). In some of the Swedish work margarine was found to be superior to butter. The Dutch workers Boer et al. (1947) attributed this to the fact that summer butter was not used in the Swedish experiments, but after further work Euler et al. (1947) were still unable to agree with the Dutch claims.

In the British work a large series of well-controlled experiments was carried out with rats in which the growth-promoting properties of butterfat were compared with those of solid, intermediate and liquid fractions of butterfat, separated by crystallization from acetone, and also with margarine and the oils of maize, cotton-seed, ground-nut and soya bean. Newly weaned litter-mate male rats were used. In some of the experiments the fats were incorporated in skim milk at a level of about $4 \%$, and in others they constituted $10 \%$ of a mixture containing ground polished rice $70 \%$, casein $5 \%$, yeast $10 \%$ and salts $5 \%$. When incorporated in milk, butterfat was not superior to margarine or to the oils of ground-nut, cotton-seed, soya bean and maize, nor was the growth obtained with a relatively saturated fraction of butterfat so good as that obtained with the unfractionated fat or with a less saturated fraction. When margarine was incorporated in the dry basal diet and given for as long as 17 weeks, growth was as great as with butter. In one of the tests with the dry basal diet, ground-nut oil gave poorer growth than butter and margarine during the latter half of a 17 week period. The ground-nut oil diet was utilized with the same efficiency as the other diets, but less of it was consumed.

The value of a number of fractions of butterfat made by precipitation from a solvent at $-7,-13,-23$ and $-53^{\circ}$ has been studied by Jack, Henderson, Reid \& Lepkovsky (1945). Unfortunately, the solvent treatment itself appeared to have some adverse effect on the fat, for when butterfat was treated with solvent and then recovered, growth 
with the recovered fat was considerably poorer than with the untreated fat. It is, therefore, difficult to interpret the results with certainty, but it is interesting to note that the poorest growth resulted from the most saturated fraction. In another series of tests the same group of workers (Henderson, Jack, Lepkovsky \& Reid, 1945) found that growth with triolein was as great as with butterfat.

It might reasonably be expected that any difference between the nutritional value of butter and that of other fats would be most readily detected by feeding experiments with calves. Gullickson \& Fountaine (1939) and Gullickson, Fountaine \& Fitch (1942) gave a number of different fats to calves for periods ranging from a few days to

Table 5. Average daily gain in weight of calves fed on milk containing different types of fat, together with the probable iodine value of the fats

(One group of calves received whole milk, another received skim milk without fat and the others received skim milk homogenized with one of the various fats.)

$\begin{array}{lcc}\text { Type of fat used } & \begin{array}{c}\text { Average gain in } \\ \text { weight* } \\ \text { (lb./day) }\end{array} & \begin{array}{c}\text { Iodine value of } \\ \text { the fat } \dagger \\ \text { (usual range) }\end{array} \\ \text { Whole milk } & 1 \cdot 43 & 26-28 \\ \text { Butterfat } & 1 \cdot 22 & 26-28 \\ \text { Lard } & 1 \cdot 17 & 47-66 \\ \text { Tallow } & 1 \cdot 24 & 35-42 \\ \text { Coconut oil } & 0.96 & 6-10 \\ \text { Low-fat diet } & 1.07 & - \\ \text { Ground-nut oil } & 0.80 & 88-98 \\ \text { Maize oil } & 0.40 & 111-128 \\ \text { Cotton-seed oil } & 0.31 & 103-11 \text { r } \\ \text { Soya-bean oil } & 0.32 & 122-134\end{array}$

- Data taken from paper by Gullickson et al. (1942). There were two to six calves in each group.

$t$ Data taken from Handbook of Chemistry and Physics (Hodgman, 1947).

6 months, beginning when the calves were $7^{-29}$ days old. The various fats were incorporated in skim milk to give liquids containing about $3.5 \%$ of fat and the mixtures were homogenized. Cod-liver oil, lucerne hay and a concentrate mixture low in fat were also given. The average daily gains in weight are shown in Table 5 . With butterfat, lard and tallow the weight gains were all of a similar order. The coconut oil gave a result similar to that for the low-fat diet, while with maize, cotton-seed and soya-bean oils growth was very poor and there was much digestive trouble and diarrhoea.

The authors do not mention the degree of unsaturation of the fats they used, but Table 5 shows that the fats which gave the poorest growth were the most unsaturated ones. It is clear that when highly unsaturated fats form the main source of fat in the diet of calves they can be harmful, a fact which recalls the well-known deleterious effect on milk secretion of giving cod-liver oil, a highly unsaturated fat, to cows (Golding, Soames \& Zilva, r926; McCay \& Maynard, r935; Hilditch \& Thompson, 1936). Much of the work which has just been discussed indicates that the unsaturated fats do not have the same ill effects on rats as on calves. It is probably not known what effect they have on man in relatively large amounts, since they are usually somewhat 
tallowy and rancid and are not likely to be eaten in any quantity, certainly not with relish. They are, of course, used in making edible fats, of which margarine is the commonest, but for that purpose they are partially hydrogenated.

One important conclusion from these calf-feeding experiments is that, since lard and tallow gave as good growth as butterfat, the lower fatty acids of butter do not appear to have any special value even for the calf, and since there is no butyric acid and only the merest trace of hexanoic and octanoic acids in human milk fat (Bosworth, 1934; Hilditch \& Meara, 1944), it seems most unlikely that they have any special value for children.

\section{Table 6. Growth of children on diets containing butter and margarine*}

(Average yearly gains of children observed for 6-24 months.)

\begin{tabular}{|c|c|c|c|c|c|c|}
\hline \multirow{2}{*}{$\begin{array}{c}\text { Age } \\
\text { (Years) }\end{array}$} & \multicolumn{3}{|c|}{ Boys } & \multicolumn{3}{|c|}{ Girls } \\
\hline & Margarine & Butter & Standard & Margarine & Butter & Standard \\
\hline \multicolumn{7}{|c|}{ Gain in weight (lb.) } \\
\hline $2-15$ & $6 \cdot 7$ & - & $7 \cdot 2$ & $8 \cdot 2$ & - & 6.9 \\
\hline $6-17$ & - & $8 \cdot I$ & $7 \cdot 9$ & - & $6 \cdot 3$ & $7 \cdot 1$ \\
\hline $6-13$ & 7.4 & $8 \cdot 7$ & $7 \cdot 5$ & 9.5 & $8 \cdot 3$ & $8 \cdot 0$ \\
\hline $10-13$ & $12 \cdot 2$ & $9 \cdot 4$ & $9 \cdot 5$ & $11 \cdot 0$ & $8 \cdot 3$ & $9 \cdot 7$ \\
\hline \multicolumn{7}{|c|}{ Gain in height (in.) } \\
\hline $2-r_{5}$ & $2 \cdot 2$ & - & $2 \cdot 3$ & $2 \cdot 2$ & - & $2 \cdot 2$ \\
\hline $6-17$ & - & $x \cdot 6$ & $\mathrm{I} \cdot 8$ & - & 0.9 & $x \cdot 7$ \\
\hline $6-13$ & $2 \cdot I$ & $2 \cdot 2$ & $2 \cdot x$ & $2 \cdot 2$ & $1 \cdot 2$ & $2 \cdot 1$ \\
\hline $10-13$ & $2 \cdot 3$ & $2 \cdot 2$ & $2 \cdot 2$ & $2 \cdot 0$ & $1 \cdot 2$ & $2 \cdot 0$ \\
\hline
\end{tabular}

In a recent experiment by Leichenger, Eisenberg \& Carlson (1948) an attempt was made to compare the value of butter and margarine for growth in children. One group of 125 children ranging in age from 6 to 17 years and housed in one institution received butter, while 130 children ranging from 3 to 16 years and housed in another institution were given margarine. The test period lasted from 6 to 24 months. About $25-30 \%$ of the calorie intake was obtained from fat, and $65-70 \%$ of the calories from fat were supplied by butter or margarine. The general health of both groups, and the red-cell counts and haemoglobin content of the blood, were all normal throughout the period of the experiment. Some of the typical results for increase in weight and height are shown in Table 6. The authors concluded that if some growth factor is present in butter and not in margarine it plays no important part in the growth of children. Curiously enough, they do not refer to the surprisingly small increase in height observed with the girls receiving butter nor to the relatively large increase in weight in the $10-13$ years group receiving margarine (Table 6).

\section{Flavour}

When Deuel, Movitt \& Hallman (1943) found that butter was not superior to many other fats and thus failed to confirm the experiments of the Wisconsin workers, they suggested that flavour might be involved. In the Wisconsin experiments feeding was 
ad lib., whereas in Deuel's work it was controlled, and it was suggested that the greater growth obtained in the earlier work with butter might have resulted from a greater consumption of the butter rations. Deuel and his colleagues found that when diacetyl, one of the substances giving butter its flavour, was added to margarine fat or groundnut oil, rats ate more of the flavoured diets in eighteen instances and of the unflavoured diets in only one instance. When 'commercial butter flavour' was used, twelve rats ate more of the flavoured food and the remaining four rats ate equal amounts of both. No animal preferred the unflavoured food.

In reply to the suggestion that flavour might explain the superior properties of butterfat noted at Wisconsin, Boutwell et al. (1944) compared the growth-promoting properties of rations containing butterfat and lactose as the sole carbohydrate with

Table 7. Average gain in weight and average food intake of male albino rats which received flavoured and unflavoured fats for 6 weeks with glucose or lactose in the diet"

$\begin{array}{lccc}\text { Nature of fat } & \begin{array}{c}\text { Nature of } \\ \text { carbohydrate }\end{array} & \begin{array}{c}\text { Average gain } \\ \text { in weight } \\ (\mathrm{g} .)\end{array} & \begin{array}{c}\text { Average daily } \\ \text { food intake } \\ (\mathrm{g} .)\end{array} \\ \begin{array}{l}\text { Butter } \\ \text { Butter from which diacetyl } \\ \text { had been removed }\end{array} & \begin{array}{c}\text { Lactose } \\ \text { Lactose }\end{array} & 145 & 9 \cdot 9 \\ \begin{array}{l}\text { Maize oil } \\ \text { Maize oil + } 5 \text { p.p.m. diacetyl }\end{array} & \text { Lactose } & 152 & 9 \cdot 7 \\ \begin{array}{l}\text { Butter } \\ \text { Maize oil }\end{array} & \text { Lactose } & 110 & 7 \cdot 7 \\ & \text { Glucose } & 124 & 8 \cdot 1 \\ & \text { Glucose } & 186 & 11 \cdot 2 \\ & \text { - From the results of Boutwell et al. (r944). }\end{array}$

similar rations containing butterfat from which diacetyl had been removed. The unflavoured diet gave as good growth as that with normal butter; maize oil was again inferior. As is shown in Table 7, butterfat and maize oil produced equal growth only when glucose was used in the diet instead of lactose. The authors suggest that by feeding ad lib. the superiority of one diet over another can be detected more readily than in controlled feeding, because the superior diet increases the growth of the animals and they then eat more food, whereas in controlled feeding they cannot eat more of the better diet and so do not grow better and differences between diets tend to be concealed. They also state that there are no data in the literature which indicate that by improving the taste of a diet the growth and food consumption of the rat are increased. But surely the results published by these authors themselves (Table 7) might be taken as supplying an example of a better flavour leading to greater food consumption and greater growth, for rats may well have a 'sweet tooth', and the substitution of the sweet sugar glucose for lactose, which has little sweetness, may have been the main reason for the fact that with the glucose diets food consumption and growth were not only equal for both fats but were much greater than they were when the carbohydrate was lactose.

The effect of flavour has been investigated further by Deuel \& Movitt (1944), who found that when butter diets were given $a d$ lib. to rats they were always eaten in greater amounts than diets containing other fats. The addition of diacetyl or of 'butter flavour' 
to the other fats, however, caused a great increase in the amounts consumed. 'Butter flavour' consisted of diacetyl, butyric acid and monobutyrin and was used in concentrations of about 4 p.p.m. It led to greater food consumption than diacetyl alone. In the experiment with children which has already been discussed Leichenger et al. (1948) found that margarine was eaten very readily provided it was coloured and served in pats like butter. When it was colourless and not in pats the children objected to it. It is obvious, therefore, that in considering the nutritive value of fats chemical composition is not the only property which matters; flavour and appearance are also of great importance.

Publications which have not been quoted but which may interest the reader include one by Bloor (1942) on the nutritive value of fats, two reports by the American Medical Association (1942, 1944) and a review article by Cowgill (1945).

\section{SUMMARY}

I. All edible fats are equally well absorbed, provided their melting-point is such that the fat can soften or liquefy in the alimentary tract.

2. The lower fatty acids of butter appear to have no special part to play in nutrition even of the very young.

3. One group of workers believes that vaccenic acid or some associated substance gives summer butter superior growth-promoting properties. Another group believes that butter is superior for very young animals only when lactose constitutes the sole carbohydrate in the diet, and that the active principle is contained in the saturated acid fraction. This latter view is not in agreement with the claims of the first group. Against both these views there is an overwhelming amount of experimental evidence which clearly suggests that butterfat is not superior to vegetable fat. From this it may be concluded that if in fact any special growth-promoting substance is present in summer butter, it is of little or no importance in practice.

4. Probably the only disadvantage of margarine at present is the fact that its flavour and appearance are frequently not equal to those of butter.

\section{REFERENCES}

Abrams, J. T., Ashton, G. C., Ritson, M. \& Wilkinson, H. (1947). Brit. F. Nutrit. I, ix.

American Medical Association, Council on Foods and Nutrition (1942). F. Amer. med. Ass. Ir9, 1425. American Medical Association, Council on Foods and Nutrition (r944). F. Amer. med. Ass. r26, r68.

Barnes, R. H., Primrose, M. F. \& Burr, G. O. (1944). Y. Nutrit. 27, 179.

Bertram, S. H. (1928). Biochem. Z. 197, 433.

Bloor, W. R. (1942). F. Amer. med. Ass. 119, ror8.

Boer, J., Jansen, B. C. P. \& Kentie, A. (1947). F. Nutrit. 33, 339.

Boer, J., Jansen, B. C. P., Kentie, A. \& Knol, H. W. (1947). F. Nutrit. 33, 359.

Bosworth, A. W. (1934). F. biol. Chem. 106, 235.

Boutwell, R. K., Geyer, R. P., Elvehjem, C. A. \& Hart, E. B. (1941). F. Dairy Sci. $24,1027$.

Boutwell, R. K., Geyer, R. P., Elvehjern, C. A. \& Hart, E. B. (1943a). F. Dairy Sci. 26, 429.

Boutwell, R. K., Geyer, R. P., Elvehjem, C. A. \& Hart, E. B. (1943b). Ұ. Nutrit. 26, 601.

Boutwell, R. K., Geyer, R. P., Elvehjem, C. A. \& Hart, E. B. (1944). Proc. Soc. exp. Biol., N.Y., 55, I53.

Burr, G. O. \& Burr, M. M. (1929). F. biol. Chem. 82, 345.

Burr, G. O. \& Burr, M. M. (1930). F. biol. Chem. 86, 587 .

Cowgill, G. R. (1945). Physiol. Rev. 25, 664 . 
Deuel, H. J. Jr. (I946). Y. Nutrit. 32,69.

Deuel. H. J. Jr. \& Hallman, L. F. (I940). F. Nutrit. 20, 227.

Deuel, H. J. Jr., Hallman, L. F. \& Leonard, A. (1940). F. Nutrit. 20, 2 r 5.

Deuel, H. J. Jr., Hallman, L. F. \& Movitt, E. (1945). F. Nutrit. 29, 309.

Deuel, H. J. Jr., Hallman, L. F., Movitt, E., Mattson, F. \& Wu, E. (1944). F. Nutrit. 27, 335 .

Deuel, H. J. Jr., Hendrick, C. \& Crockett, M. E. (1946). F. Nutrit. 3r, 737.

Deuel, H. J. Jr., Hendrick, C., Movitt, E., Crockett, M. E., Smyth, I. M. \& Winzler, R. J. (1946). F. Nutrit. 3I, 747 .

Deuel, H. J. Jr. \& Holmes, A. D. (1921). Amer. F. Physiol. 54, 479.

Deuel, H. J. Jr. \& Holmes, A. D. (1922). Bull. U.S. Dep. Agric. no. I033.

Deuel, H. J. Jr. \& Movitt, E. (1944). F. Nutrit. 27, 339.

Deuel, H. J. Jr. \& Movitt, E. (1945). F. Nutrit. 29, 237.

Deuel, H. J. Jr., Movitt, E. \& Hallman, L. F. (1943). Science, 98, 139.

Deuel, H. J. Jr., Movitt, E. \& Hallman, L. F. (I944). F. Nutrit. 27, 509.

Deuel, H. J. Jr., Movitt, E., Hallman, L. F. \& Mattson, F. (1944). F. Nutrit. 27, ro7.

Euler, B. v., Euler, H. v. \& Rönnestam-Saberg, I. (1947). Ark. Kemi Min. Geol. [B], 25, no. 2.

Euler, B. v., Euler, H. v. \& Säberg, I. (1942). Ernährung, 7, 65.

Euler, B. v., Euler, H. v. \& Saberg, I. (1943). Ernährung, 8, 257.

Golding, J., Soames, K. M. \& Zilva, S. S. (1926). Biochem. Y. 20, 1306.

Gullickson, T. W. \& Fountaine, F. C. (1939). F. Dairy Sci. 22, 47r.

Gullickson, T. W., Fountaine, F. C. \& Fitch, J. B. (1942). f. Dairy Sci. 25, Ir7.

Harris, R. S. \& Mosher, L. M. (x940). Food Res. 5, 177.

Henderson, J. L., Jack, E. L., Lepkovsky, S. \& Reid, D. L. (1945). Y. Nutrit. 30, 169.

Henry, K. M., Kon, S. K., Hilditch, T. P. \& Meara, M. L. (1945). J. Dairy Res. 14, 45.

Hilditch, T. P. \& Thompson, H. M. (1936). Biochem. F. 30, 677 .

Hilditch, T. P. \& Meara, M. L. (1944). Biochem. F. 38, 29.

Hodgman, C. D. (Editor) (1947). Handbook of Chemistry and Physics, 3oth ed. Ohio: Chemical Rubber Publishing Co.

Holmes, A. D. (1925). Boston med. surg. Y. 192, 1210.

Jack, E. L., Henderson, J. L., Reid, D. F. \& Lepkovsky, S. (1945). F. Nutrit. 30, 175.

Jansen, B. C. P. (1948). Chem. $\mathcal{E}^{\circ}$ Ind. Supplement on the 9 th International Congress of Pure and Applied Chemistry, London, 1947, p. 13.

Kentie, A. (1947). Ned. Melk Zuiveltijdschr. r, 118.

Langworthy, C. F. (1923). Industr. Engng Chem. 15, 276.

Leichenger, H., Eisenberg, G. \& Carlson, A. J. (1948). F. Amer. med. Ass. 136, 388.

McCay, C. M. \& Maynard, L. A. (1935). F. biol. Chem. 109, 29.

Parrish, D. B., Shimer, E. R. \& Hughes, J. S. (1946). F. Nutrit. 31, 321.

Schantz, E. J., Boutwell, R. K., Elvehjem, C. A. \& Hart, E. B. (1940a). F. Dairy Sci. 23, I201.

Schantz, E. J., Boutwell, R. K., Elvehjem, C. A. \& Hart, E. B. (I940b). F. Dairy Sci. 23, 1205.

Schantz, E. J., Elvehjem, C. A. \& Hart, E. B. (1937-8). F. biol. Chem. r22, 381.

Schantz, E. J., Elvehjem, C. A. \& Hart, E. B. (1940). F. Dairy Sci. 23, 18 r.

Steenbock, H., Irwin, M. H. \& Weber, J. (1936). F. Nutrit. 12, 103.

Zialcita, L. P. \& Mitchell, H. M. (I944). Science, roo, 60.

\section{Heated Fats as a Possible Source of Carcinogens}

\section{By P. R. Peacock, Royal Cancer Hospital, Glasgow}

Cancer of the stomach causes more deaths in temperate zones of the world than any other form of malignant disease. It is natural, therefore, to consider whether this high incidence is attributable to some essentially human propensity or habit, or whether it is merely an inevitable consequence of an increase in expectation of life. The distribution of cancer in the population is about evenly divided between those under 65 and those over 65 , although less than one-tenth of the population is in the latter group.

Although human statistics are bound to be inaccurate, the tendency is to avoid notifying death as due to cancer unless the diagnosis is considered certain; the numbers, 